\title{
Kidney Ultrasound Elastography: Review
}

\section{Böbrek Ultrason Elastografisi: Derleme}

\author{
Mahmut Duymuș', Mehmet Sait Menzilcioğlu', Mustafa Gök², Serhat Avcu' \\ ${ }^{1}$ Gazi University Faculty of Medicine, Department of Radiology, Ankara; ${ }^{2}$ Adnan Menderes University Faculty of Medicine, Department of \\ Radiology, Aydin
}

\begin{abstract}
Kidneys are the most important and the functional organs in the body. There are numerous of disorders affecting the kidneys. The most important disorder is chronic kidney disease because of being costly and going to failure. In recent years ultrasound elastography technics showed increasing development line, and more studies were performed about elastography on kidneys. The weighted amount of the elastography studies are about chronic kidney disease, kidney failure and allograft patients, while some of them are about kidney masses or diabetic nephropathy. Various studies presented various results. In this review we want to present the elastography studies about kidney.
\end{abstract}

Key words: kidney; elastography; chronic kidney disease

\section{ÖZET}

Böbrekler çok önemli ve fonksiyonel organlardır. Böbreği etkileyen çok sayıda hastalık vardır. Kronik böbrek hastalığı yüksek maliyeti ve yetmezliğe ilerlemesi nedeniyle en önemli hastalıktır. Son yıllarda sonoelastografi tekniği yükselen bir grafik çizmektedir ve böbrekler üzerinde sonoelastografi tekniği kullanılarak yapılmıș değișik çalıșmalar mevcuttur. Bu çalıșmaların çoğunluğu kronik böbrek hastalığı, böbrek yetmezliği ve allograft hastalarını konu alıken, bazıları böbrek kitleleri ve diabetik nefropati hakkındadır. Farklı çalıșmalarda farklı sonuçlar sunulmuștur. Bu derlemede böbrekler hakkında yapılan sonoelastografi çalıșmalarını sunmayı planladık.

Anahtar kelimeler: böbrek; elastografi; kronik böbrek hastalığı

\section{Abbreviations (Listed in Alphabetical Order)}

Acoustic Radiation Force Impulse Elastography (ARFI)

Angiomyolipoma (AML)

Chronic Allograft Injury (CAI)

Chronic Allograft Nephropathy (CAN)

Chronic Kidney Disease (CKD)

Dimercaptosuccinic acid (DMSA)

estimated Glomerular Filtration Rate (eGFR)

Glomerular Filtration Rate (GFR)

Intravenous Pyelography (IVP)

kiloPascal $(\mathrm{kPa})$

Magnetic Resonance Imaging (MRI)

Yard. Doc. Dr. Mabmut Duymus, Gazi Üniversitesi T⿰р Fakültesi, Radyoloji Anabilim Dal, Ankara,Türkiye, Tel.03122126840Email.mahmutduymush@yahoo.com Gelis Taribi: 13.04.2016 • Kabul Tarihi: 21.06.2016
Pulsatility Index (PI)

Renal Cell Carcinoma (RCC)

Resistive Index (RI)

Real-time sonoelastography (RSE)

Region of Interet (ROI)

Real-time elastography (RTE)

Renal Transplant Recipients (RTRs)

Strain Elastography (SE)

Strain Index (SI)

Strain Ratio (SR)

Supersonic Shear Imaging (SSI)

Shear-wave Elastography (SWE)

Shear Wave Speed (SWS)

Shear Wave Velosity (SWV)

Transient Elastography (TE)

Tissue Mean Elasticity (TME)

Ultrasonography (USG, US)

Vesico Ureteral Reflux (VUR)

Zero-Crossing (ZC)

\section{Kidneys}

Kidneys are vital and important organs, anatomically and functionally depicted as parenchyma and sinus. Parenchyma consists of cortex and medulla, and sinus consists of fat, tubulary collecting system, pelvis, blood vessels and nerves ${ }^{1}$. There are numerous of disorders affecting the kidneys. Some of them are functional, systemic and diffuse, while some are local and massy, and also vascular, congenital, hereditary and acquired ${ }^{2,3}$. Among all the disorders, chronic kidney disease (CKD) and transplanted kidneys are the subject of elastography in a majority of studies ${ }^{4-14}$. CKD is an important and costly health problem because of not only the increasing incidence and prevalence but also resulting in endstage renal failure. The progression of CKD shows fibrosis involving first glomeruli or interstitial space ${ }^{15-19}$. Fibrosis can be detected only by the biopsy procedure, which is interventional and non confortable for the patients. To detect the fibrosis, non-invasive and quickly obtained methods are essential for nephrologists not 
to waste time and to plan the treatment. The fibrosis changes the microstructure and elasticity of the tissue ${ }^{20}$. Elastography presents the elasticity of the tissue but has not been placed in the routine diagnostic algorithm of the kidney disorders. In this review, we aim to discuss the USG elastography method in kidney disorders with the literature background.

\section{Elastography}

Elastography was first described by Ophir et al. ${ }^{21}$. The working principle of elastography is based on the lesion or tissue stiffness. Standard USG device and elastography software are enough to establish the elastography. Basicly two types of elastography can be counted as quasci static and dynamic differentiating each other from data collecting way and the software. Strain elastography (SE) is quasci static method. Shearwave Elastography (SWE), Acoustic Radiation Force Impulse Elastography (ARFI) and Transient elastography (TE) are the dynamic types ${ }^{22,23}$.

\section{Dynamic Methods}

\section{(Acoustic Radiation Force Impulse Elastography, Shear-Wave Elastography, and Transient Elastography)}

Shear-wave elastography uses shear-waves to collect the data. The propagation speed of the shear wave is measured in this method. The software processes the shearwave propagation in very very short time and quickly (20.000 frame in second) and presents the quantitable values. The unit of shear wave is $\mathrm{m} / \mathrm{sec}$ and the tissue elasticity is kiloPascal ( $\mathrm{kPa}$ ) (Fig. 1 and Fig. 2). The elasticity formula is $\mathrm{E}=\rho c^{2}$. The ' $\mathrm{E}$ ' indicates the tissue elasticity, ' $\rho$ ' $\left(\mathrm{kg} / \mathrm{cm}^{3}\right)$ indicates the tissue density, while ' $\mathrm{c}$ ' ( $\mathrm{m} / \mathrm{sec})$ indicates the shear-wave speed. But SWE has some limitations, such as lack of measurement in ascites medium. The operator independency is the superiority of SWE 22,24 . The major handicap of SWE is the anisotropy, which is related with the tissue structure and the beam distribution. The renal cortical structure shows radial distribution from hilus to cortex. The USG beams come in different angles to the poles and equator of the kidney. If the beams come parallel to these structures, shear waves propagate perpendicularly, while beams come perpendicular shear waves propagate parallelly. This anisotropy causes disconcordance in the values of poles and equator ${ }^{23,25}$.

ARFI is another method that uses shear-waves as SWE does. But the data acquisition of ARFI is different from the SWE. In ARFI the high energized short term
(0.03-0.04 msec) acoustic pulses, make the micrometric $(1-20 \mu \mathrm{m})$ displacements in the examined tissue. Square shaped Region of Interet (ROI) is used to measure the micrometric displacements. The displacement generates the shear-waves. ARFI uses the displacement of the examined tissue using shear waves, but does not use the speed of shear-wave unlike SWE. The soft tissues are bright, while the hard tissues are dark in ARFI in gray scale screen. The unit of ARFI is $\mathrm{m} / \mathrm{sec}$. Operator independency and the quantitative data presentation are the advantages of ARFI, but does not have capability to present data

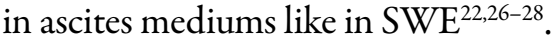

TE is one of the methods that use shear-waves. The main usage area and the studies about TE is based on the liver. In this method, the USG probe applies external mechanical impulse to the related tissue, thus shear-wave generates in the related tissue. The speed and the displacement of the shear wave according to the deepness generate an image like in M-mode. So the major handicap of TE is lack of gray scale B-mode USG images. TE can only serve the M-mode USG images. The speed of the shear wave increases with the stiffness of the tissue. TE can not be used in the existence of perihepatic fluid. The evaluated area is 200 times bigger $\left(3 \mathrm{~cm}^{3}\right)$ than the biopsy. The unit of TE is $\mathrm{kPa}$. In $\mathrm{TE}$, the inter and the intra-observer variability is minimal. But there are also some limitations, such as obesity, does not have capability to present data in ascites mediums and in focal lesion. The main limitation about liver is the non capability of measurement in left lobe l2,23,28-32. $^{2}$.

\section{Quasi Static Method (SE)}

Strain Elastography is different from shear-wave elastography methods in some ways. In SE the acoustic force is applied by the operator manually. The operator does not only produce the acoustic force, but also produces the dynamic force to the examined tissue, thus this method is semi-static. The operator or transducer applies compression and decompression pulses to the related lesion. The measurements should be collected in the decompression phase, to avoid the pressure effect. SE measures the displacement and the deformation of the lesion. The unit of SE is Strain Index (SI). SI, means the stiffness ratio of the adjacent tissue compared to the examined lesion. The stiffness of the hard lesions is higher, thus the displacement and deformation is lower. So, the strain of hard lesions is lower, but the SI of hard lesions is higher, because of the ratio. In this method, two ROIs 

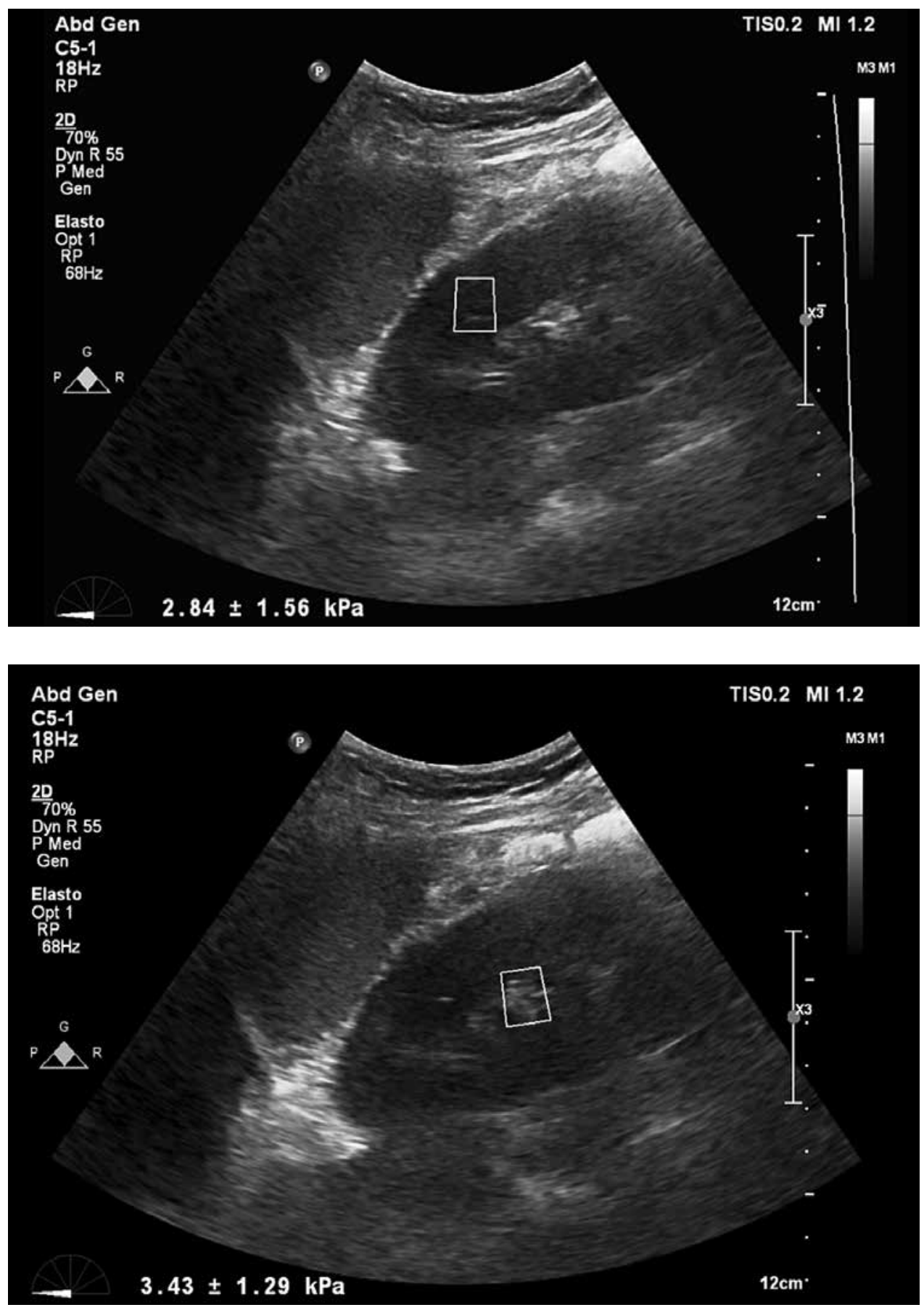

Figure 1. Shear wave elastography image of kidney parenchyma. The square indicates the measurement localization. The number below the figure indicates stiffness of the tissue in the unit of $\mathrm{kPa}$.
Figure 2. Shear wave elastography image of kidney sinus. The square indicates the measurement localization. The number below the figure indicates stiffness of the tissue in the unit of $\mathrm{kPa}$. are required to measure and compare the stiffness (Fig. 3 and Fig. 4). The major limitation of the SE is operator dependency. The window width and the transducer pressure affects the image quality. The window should be arranged as optimal as the lesion size. The compression and the decompressions should be done slightly and not very slow or not very fast $(0.5-2$ compressions in a second). The distance between the lesion and the transducer should be less than $3-4 \mathrm{~cm}$ to acquire more reliable data. This method has an advantage about providing data in ascites medium, unlike others ${ }^{20,22,23,33,34}$.

The major limitation of all elastography methods are small sample size. For example strain ratio needs to rate 

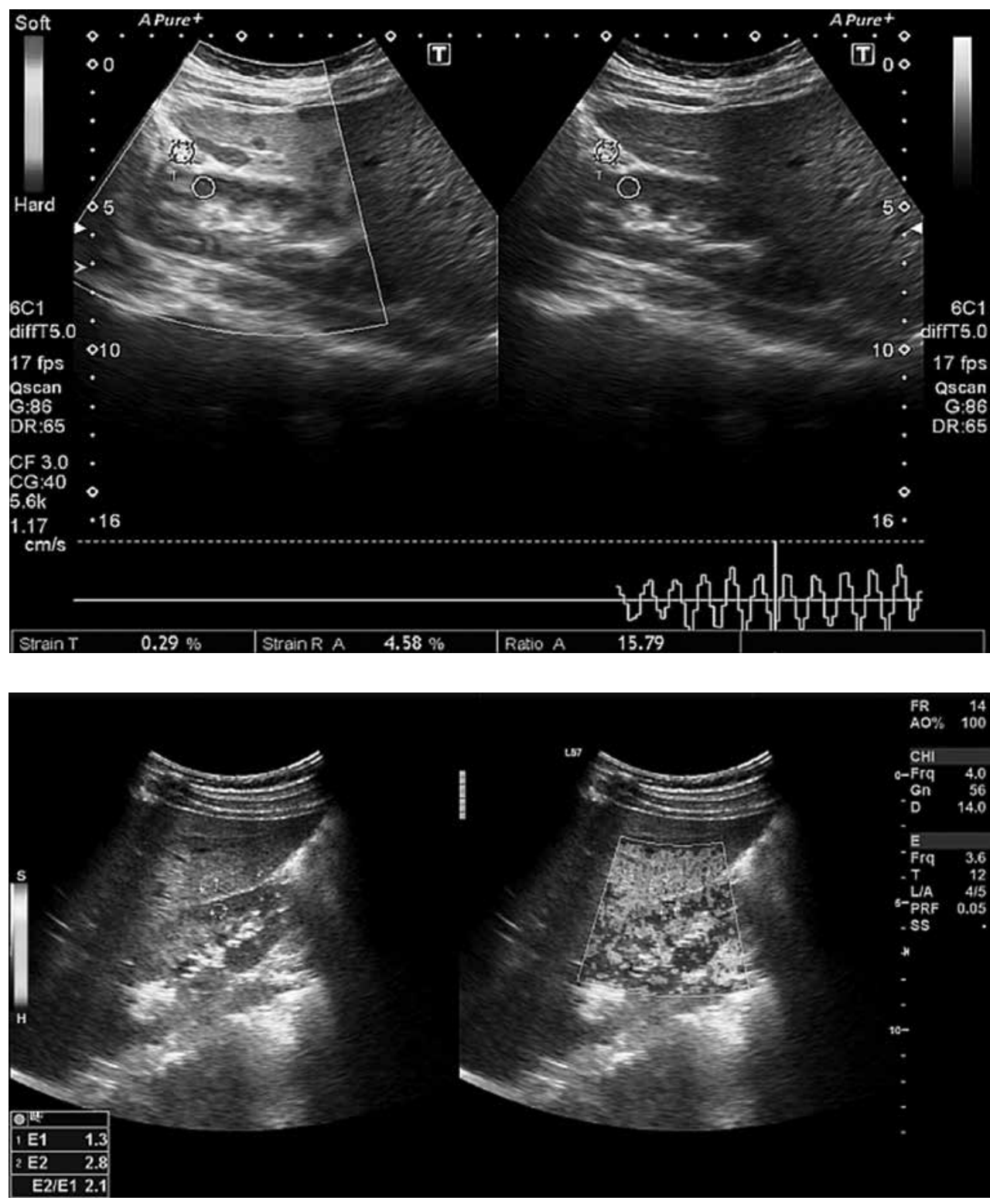

Figure 3. Strain elastography image of the kidney parenchyma. The image shows active elastography mode of ultrasonography (USG). The screen was divided into three parts as right, left and bottom. The color coded left side indicates elastography mode, while the right side is gray scale $B$-mode USG image. The bottom indicates the sinusoidal wave, which allows the operator to follow the compression and decompressions. The circles indicates the region of interests (ROI). One ROI was adjusted to the parenchyma while the other was in the perirenal fat tissue. The strain ratio was given below the screen.

Figure 4. Strain elastography image of the kidney parenchyma. The right side of the image indicates the elastography mode. Two ROls seen in the left side image. One of them was udjusted to the liver parenchyma while the other was on the kidney parenchyma. The numbers below the screen indicates the strain ratio of the parenchyma and the adjacent tissue. the two adjacent tissue. The operator can only adjust the ROI size according to the parenchyma/sinus and the perisplenic soft tissue. To avoid the tissue wrong sampling, operator should use maximum sampling ROIs. Maximum ROI should present the the more reliable value. But using maximum ROI will take a lot of time. In addition to ROI size, the organs have three dimensions but the US systems allows the operator to measure in two dimension. If operator can measure whole the kidney this measurement will present only two dimentional one slice value ${ }^{35}$. This means that, operator should take more measurements from different aspects of the kidney. This procedure also takes more time.

\section{Literature Review}

In the advanced search mode of Pubmed using the words 'kidney elastography', picking the MeSH terms and Title/Abstract, 49 results were listed. Some of them were about animals ${ }^{36-42}$, some of them were about MRI or MR elastography ${ }^{43-52}$, some of them were about other organ systems $s^{53-65}$, some of them were about elastography technic ${ }^{28,66-69}$ and some of them were about non elastography related kidney studies ${ }^{70}$. We excluded these articles. The rest amount of related articles were $13^{4,5,8-}$ $11,13,14,25,71-74$. But, pubmed search missed some articles $^{6,7,12,35,75}$, that was mentioned in this paper (Table 1). 
Table 1. The articles that we discussed

\begin{tabular}{|c|c|c|c|}
\hline Reference & $\begin{array}{l}\text { Elastography } \\
\text { type }\end{array}$ & Patient population & Study design \\
\hline $\begin{array}{l}\text { Ardnt } 2010 \text { et al. } \\
\text { Noninvasive evaluation of renal } \\
\text { allograft fibrosis by transient } \\
\text { elastography--a pilot study }\end{array}$ & TE (Fibroscan) & $\begin{array}{l}\text { Renal transplanted } \\
55 \text { patients, } \\
\text { Biopsies were } \\
\text { performed in } 20 \\
\text { patients. }\end{array}$ & $\begin{array}{l}\text { Evaluates the feasibility of TE for the assessment of renal } \\
\text { allograft fibrosis. Stiffness was significantly correlated to } \\
\text { the extent of interstitial fibrosis (Pearson } r: 0.67, P: 0.002 \text {, } \\
R(2): 0.45) \text { and inversely related to eGFR (Pearson } r:-0.47 \text {, } \\
P: 0.0003, R(2): 0.22) \text {. The stiffness values of chronic } \\
\text { allograft injury Banff grades } 0-1 \text { differed significantly from } \\
\text { grade } 2(P: 0.008) \text { and grade } 3(P: 0.046) \text {. }\end{array}$ \\
\hline $\begin{array}{l}\text { Asano et al. } \\
\text { Acoustic radiation force impulse } \\
\text { elastography of the kidneys: is } \\
\text { shear wave velocity affected by } \\
\text { tissue fibrosis or renal blood flow? }\end{array}$ & $\begin{array}{l}\text { ARFI (Siemens } \\
\text { Acoson S2000) }\end{array}$ & $\begin{array}{l}319 \text { CKD, } 14 \\
\text { healthy volunteers }\end{array}$ & $\begin{array}{l}\text { Identify the main influencing factor of the SWV. The SWV } \\
\text { decreased concurrently with a decline in the eGFR. A low } \\
\text { SWV was obtained in patients with a high brachial-ankle } \\
\text { pulse wave velocity. Despite progression of renal fibrosis in } \\
\text { the advanced stages of CKD, these results were in contrast } \\
\text { to findings for chronic liver disease, in which progression } \\
\text { of hepatic fibrosis results in an increase in the SWV. } \\
\text { Considering that a high brachial-ankle pulse wave velocity } \\
\text { represents the progression of arteriosclerosis in the large } \\
\text { vessels, the reduction of elasticity succeeding diminution of } \\
\text { blood flow was suspected to be the main influencing factor } \\
\text { of the SWV in the kidneys. }\end{array}$ \\
\hline
\end{tabular}

Dillman et al.

Can Shear-Wave Elastography

be Used to Discriminate

Obstructive Hydronephrosis from

Nonobstructive Hydronephrosis in

Children?

\section{SWE (Siemens) 37 children}

\section{Children underwent elastography of the kidneys} immediately before and immediately after diuretic renal scintigraphy (reference standard for presence of urinary tract obstruction).

Median SWS measurements, as well as change in median SWS (median SWS after diuretic administration minus median SWS before diuretic administration) were correlated with the amount of time required for kidney radiotracer activity to fall by $50 \%$ after intravenous administration of the diuretic ( $\left.\mathrm{T}_{12}\right)$. Median SWS measurements were compared with degree of obstruction and degree of hydronephrosis with analysis of variance. renal cortical fibrosis
Gao 2013 et al.

Renal transplant elasticity ultrasound imaging: correlation between normalized strain and

SE

(Echolnsight,

Epsilon

Imaging)

SE (Siemens

Acuson

Sequoisa 512)

Corticomedullary strain ratio: a

quantitative marker for assessment
Renal allograft 33 patients
20 renal transplant

The hardness of the renal cortex in renal transplant allograft patients using a normalized ultrasound strain procedure measuring quasi-static deformation. Normalized strain is defined as the mean developed strain in the renal cortex divided by the overall mean strain measured in the soft tissues from the abdominal wall to pelvic muscles. Banff scoring.

Correlation between the corticomedullary SR and cortical fibrosis in renal transplants. on Banff scoring. We calculated the corticomedullary SR (cortical normalized strain/medullary normalized strain; normalized strain $=$ developed strain/applied strain [deformation from the abdominal wall to the pelvic muscles]).

Conclusion

Parenchymal stiffness measured by TE reflects interstitial fibrosis in kidney allografts.

Diminution of blood flow may affect SWV values in the kidneys more than the progression of tissue fibrosis.

US SWS measurements did not enable discrimination of obstructive hydronephrosis from unobstructive hydronephrosis in children.

Renal cortex strain is strongly correlated with grade of renal cortical fibrosis. Normalized strain is superior to developed strain in distinguishing moderate from mild renal cortical fibrosis.

Strain values vary in different compartments of the kidney. The corticomedullary SR on USG elasticity imaging decreases with increasing renal cortical fibrosis which makes it potentially useful as a noninvasive quantitative marker for monitoring the progression of fibrosis in renal transplants.

SE (quasi-

static ultrasound elastography

38 renal transplant patients

elasticity measurement in assessment of renal allograft cortical hardness: a preliminary observation

Goya 2015 et al

The role of quantitative measurement by acoustic radiation force impulse imaging in differentiating benign renal lesions from malignant renal tumours
ARFI (Siemens 60 patients with Evaluate the diagnostic performance of ARFI for Acoson S2000) renal lesions; benign, malign and infectious
USG strain ZC elasticity measurement can be used to discriminate moderate cortical fibrosis or inflammation in renal allografts, we assessed cortical hardness with quasistatic USG elastography in renal transplant patients who underwent kidney biopsy. Banff scoring. differentiating benign lesions from malignant renal tumours. The final diagnoses were determined via pathologic $(n=33)$, clinical $(n=13)$ and imaging findings $(n=14)$. The SWV values of the renal tumours were analysed according to the final diagnoses.
$\mathrm{ZC}$ is a new strain marker that could be straightforward to interpret and perform, making it a potentially practical approach for monitoring progression of cortical fibrosis or inflammation in renal allografts.

ARFI imaging may be useful for differentiating between benign renal lesions and malignant renal tumours. 
Table 1 (continued). The articles that we discussed

\begin{tabular}{l}
\hline Reference \\
\hline Goya 2015 et al. \\
Acoustic radiation force impulse \\
(ARFI) elastography for detection of \\
renal damage in children \\
Goya 2015 et al. \\
Acoustic radiation force impulse \\
imaging for evaluation of renal \\
parenchyma elasticity in diabetic \\
nephropathy
\end{tabular}

Grenier 2011 et al.

[Imaging and renal failure: from inflammation to fibrosis]

Grenier 2013 et al.

Renal ultrasound elastography

Grenier et al., 2012

Quantitative elastography of renal

transplants using supersonic shear

imaging: a pilot study

He WY 2014

Tissue elasticity quantification by

acoustic radiation force impulse for

the assessment of renal allograft

function

Lukenda V 2014

Transient elastography: a new

noninvasive diagnostic tool for

assessment of chronic allograft

nephropathy

Menzilcioğlu 2015 et al.

Strain wave elastography for

evaluation of renal parenchyma in

chronic kidney disease

Orrlachio 2014 et al.

Kidney transplant: usefulness of

real-time elastography (RTE) in the

diagnosis of graft interstitial fibrosis

Özkan 2013 et al.

Interobserver variability of

ultrasound elastography in

transplant kidneys: correlations with

clinical-Doppler parameters

Tan 2013 et al.

Real-time elastography for distinguishing angiomyolipoma from renal cell carcinoma:

preliminary observations

\begin{tabular}{ll}
$\begin{array}{l}\text { Elastography } \\
\text { type }\end{array}$ & Patient population \\
\hline $\begin{array}{l}\text { ARFI (Siemens } \\
\text { Acoson S2000) }\end{array}$ & $\begin{array}{l}88 \text { children, 20 } \\
\text { healthy controls }\end{array}$ \\
ARFI (Siemens & 114 diabetic \\
Acoson S2000) & $\begin{array}{l}\text { nephropathy, } 281 \\
\text { healthy }\end{array}$
\end{tabular}

ARFI (Siemens 114 diabetic healthy

changes in the elasticity of the renal parenchyma in diabetic nephropathy using ARFI acoustic radiation force impulse imaging. The changes in the renal elasticity were compared between the different stages of diabetic nephropathy and the healthy control group.

severity of renal damage on DMSA scintigraphy.

Conclusion

Decreasing SWV of renal

units with increasing

with and without VUR. Patients were assessed according to grades of VUR.

ARFI imaging could be used for the evaluation of the renal elasticity changes that are due to secondary structural and functional changes in diabetic nephropathy.

Article in French

Review

SWE

43 kidney transplant recipient followed by biopsy

The reliability of quantitative ultrasonic measurement of renal allograft elasticity using SSI. Banff score.

ARFI

TE (Fibroscan Echosense)

52 stable renal function, 50 biops proven allograft dysfunction

Renal allograft stiffness using ARFI quantification in patients with stable renal function and those with biopsyproven allograft dysfunction. ARFI quantification, given as SWV. The RI was calculated by pulsed-wave Doppler ultrasound, and clinical and laboratory data were collected.

52 Renal transplant recipies

CAN is the most common cause of kidney allograft failure. Protocol biopsies remain the "gold standard" in CAN recognition. Usefulness of TE for the assessment of kidney allograft fibrosis in RTRs.

SE (Toshiba

Aplio 500)

58 patients with CKD, 40 healhty individuals

Determine the difference of SI value of renal parenchyma between patients with CKD and healthy individuals.

SE (real-time elastography- 50 patients RTE) graft fibrosis

Evaluate the usefulness of RTE in the diagnosis of graft interstitial fibrosis. TME was calculated by two blinded operators. All patients underwent biopsy after RTE. Banff score.

\section{SE (real-time 42 adult renal} elastography- transplant RTE) recipients
Evaluate the ability of investigators to use sonoelastography to detect differences in renal cortical stiffness and assess the relationship between stiffness and clinical-Doppler parameters.
SE (real-time $\quad 47$ lesion detected elastography- patients RTE) (GE Logiq 19 RCC, 28 AML
Diagnostic performance of sonoelastography for differentiating AML from RCC. The elasticity patterns and the strain ratio were evaluated independently by two observers. Blue areas in $<50 \%$ of lesion, considered type 1 or type 2) by both radiologists, whereas 18 of 19 renal cell carcinomas were classified as having a low-strain elastographic pattern (blue areas in $>I=50 \%$ of lesion, considered type 3 or 4) by both radiologists.
Quantitative measurement of renal cortical stiffness using SSI is a promising non-invasive tool to evaluate global histological deterioration.

Tissue elasticity quantification by ARFI is more accurate than the $\mathrm{Rl}$ in diagnosing renal allograft function.

Parenchymal stiffness obtained by TE reflects interstitial fibrosis. Therefore, TE provides the opportunity for noninvasive screening of CAN.

SI value can be used to differentiate patients with CKD and healthy individuals. We have not shown that it can reliably differentiate different stages.

RTE was able to evaluate kidney fibrosis and could be used as complementary imaging during follow-up of renal transplant patients.

SR showed significant positive correlation with $\mathrm{Rl}$ and $\mathrm{Pl}$ but sonoelastography has also wide range intra- and low interobserver agreement in renal transplants.

Real-time elastography may be useful in differentiating AML from RCC, by use of both elasticity patterns and strain ratios.

TE, transient elastography; eGFR, estimated glomerular filtration rate; ARFI, acoustic radiation force impulse elastography; CKD, chronic kidney disease; SWV, shear-wave velosity; SWE, shear-wave elastography; SWS, shear-wave speed; US, ultrasonography; SR, strain ratio; USG, ultrasonography; ZC, zero-crossing; VUR, Vesico ureteral reflux; DMSA, dimercaptosuccinic acid; SSI, supersonic shear imaging; $\mathrm{RI}$, resistive index; CAN, chronic allograft nephropathy; RTRs, renal transplant recipients; RTE, real-time sonoelastography; TME, tissue mean elasticity; AML, angiomyolipoma; RCC, renal cell carcinoma. 
Table 2. Summary of the studies according to patient population, elastography type and study design

\begin{tabular}{|c|c|}
\hline Children & Dillman et al., Goya et al. 2015 \\
\hline Transplanted kidney & $\begin{array}{l}\text { Arndt et al., Gao } 2013 \text { et al., Gao } 2013 \text { et al., Gao } 2014 \text { et al., Grenier et al., He WY et al., Lukenda et al., Orlacchio et al., } \\
\text { Ozkan et al. }\end{array}$ \\
\hline CKD & Asano et al., Menzilcioğlu et al. \\
\hline SWE (ARFI, SWE and TE) & $\begin{array}{l}\text { Arndt et al., Asano et al., Dillman et al., Goya } 2014 \text { et al., Goya } 2015 \text { et al., Goya } 2015 \text { et al., Grenier et al., He WY et al., } \\
\text { Lukenda et al. }\end{array}$ \\
\hline SE & Gao 2013 et al., Gao 2013 et al., Gao 2014 et al., Menzilcioğlu et al., Orlacchio et al., Özkan et al., Tan et al. \\
\hline Inter-intraobserver variability & Asano et al., Goya 2015 et al., Grenier et al., Orlacchio et al., Özkan et al. \\
\hline Mass & Goya 2015 et al., Tan et al. \\
\hline Diabetic nephropathy & Goya 2015 et al. \\
\hline
\end{tabular}

In the studies about $\mathrm{CKD}$, renal transplant recipient (end-stage CKD) or transplanted patients most of the studies revealed that elastography allows the operator to differentiate the fibrotic cortex from non-fibrotic freely from the elastography method (Table 2). Anyway, there is no adequate and reliable data about differentiating the grades of fibrosis ${ }^{4-14}$. Perhaps in near future these results should assist the clinicians to use elastography instead of biopsy. It is obviously clear that more studies are needed about elastography and kidneys. Althouh there is a consensus about differentiating the fibrosis, inter and intra-observer compatibility is low yet ${ }^{5,14}$. This may be related with the different measurement points (adjusting the ROI different regions) and the lack of number of samples. The more sampling should increase the inter and intra-observer compatibility.

Cortical elasticity has not only the field about CKD but also can be used in the diabetic nephropathy. Goya et al reported a treshold to distinguish the diabetic kidney and apparently normal kidney with the sensitivity of $84.1 \%$ and the specificity of $67.3 \%{ }^{72}$.

There are few studies about children. Goya was reported decrement in SWV with increasing grades of VUR, while Dilman reported as elastography did not allow to disctriminate the obstructive hydronephrosis fron non-obstructive hydronephrosis ${ }^{35,75}$.

Goya et al and Tan et al used elastography for characterization of the masses. Goya et al reported that benign and malignant lesions' SWV were higher than those of intact renal parenchyma, while haematomas' SWV values were lower ${ }^{71}$. Tan et al focused on the angiomyolipomas (AML) and renal cell carcinomas (RCC), using two different observers and real time elastography. In conclusion they finished suggesting real-time elastography to differentiate RCC and $\mathrm{AML}^{74}$.

\section{Conclusion}

Sonographic elastography is a new developing technic, and various studies have been made using elastography in kidneys. Most of the studies are made on the transplanted or CKD kidneys to evaluate the effectiveness of elastography in the evaluation of corticomedullary fibrosis to preserve the patient from the invasive method, biopsy. And also most of the studies were performed using SWE elastography. The results showed that, SWV values increase with the degree of fibrosis and perhaps in near future especially SWE would take the place of biopsy.

\section{References}

1. Rha SE, Byun JY, Jung SE, et al. The Renal Sinus: Pathologic Spectrum and Multimodality Imaging Approach. RadioGraphics 2004;24:S117-31.

2. Seçil M. Böbrekler. Temel Ultrasonografi ve Doppler. İzmir: Meta Basım Matbaacilık Hizmetleri; 2013;310-60.

3. Tuncel E. Boşaltım ve Üreme Sistemi. Klinik Radyoloji. Bursa: Nobel \& Güneş Tip Kitabevi; 2008:541-670.

4. Arndt R, Schmidt S, Loddenkemper C, et al. Noninvasive evaluation of renal allograft fibrosis by transient elastography $-\mathrm{a}$ pilot study. Transpl Int 2010;23:871-7.

5. Asano K, Ogata A, Tanaka K, et al. Acoustic radiation force impulse elastography of the kidneys: is shear wave velocity affected by tissue fibrosis or renal blood flow? J Ultrasound Med 2014;33:793-801.

6. Gao J, Min R, Hamilton J, et al. Corticomedullary strain ratio: a quantitative marker for assessment of renal allograft cortical fibrosis. J Ultrasound Med 2013;32:1769-75. 
7. Gao J, Rubin JM. Ultrasound strain zero-crossing elasticity measurement in assessment of renal allograft cortical hardness: a preliminary observation. Ultrasound Med Biol 2014;40:2048-57.

8. Gao J, Weitzel W, Rubin JM, et al. Renal transplant elasticity ultrasound imaging: correlation between normalized strain and renal cortical fibrosis. Ultrasound Med Biol 2013;39:1536-42.

9. Grenier N, Poulain S, Lepreux S, et al. Quantitative elastography of renal transplants using supersonic shear imaging: a pilot study. Eur Radiol 2012;22:2138-46.

10. He WY, Jin YJ, Wang WP, et al. Tissue elasticity quantification by acoustic radiation force impulse for the assessment of renal allograft function. Ultrasound Med Biol 2014;40:322-9.

11. Lukenda V, Mikolasevic I, Racki S, et al. Transient elastography: a new noninvasive diagnostic tool for assessment of chronic allograft nephropathy. Int Urol Nephrol 2014;46:1435-40.

12. Menzilcioglu MS, Duymus M, Citil S, et al. Strain wave elastography for evaluation of renal parenchyma in chronic kidney disease. Br J Radiol 2015;88:20140714.

13. Orlacchio A, Chegai F, Del Giudice C, et al. Kidney transplant: usefulness of real-time elastography (RTE) in the diagnosis of graft interstitial fibrosis. Ultrasound Med Biol 2014;40:2564-72.

14. Ozkan F, Yavuz YC, Inci MF, et al. Interobserver variability of ultrasound elastography in transplant kidneys: correlations with clinical-Doppler parameters. Ultrasound Med Biol 2013;39:4-9.

15. Coresh J, Selvin E, Stevens LA, et al. Prevalence of chronic kidney disease in the United States. Jama 2007;298:2038-47.

16. Guo LH, Xu HX, Fu HJ, et al. Acoustic radiation force impulse imaging for noninvasive evaluation of renal parenchyma elasticity: preliminary findings. PLoS One 2013;8: e68925.

17. Meguid El Nahas A, Bello AK. Chronic kidney disease: the global challenge. Lancet (London, England) 2005;365:331-40.

18. Chatziantoniou C, Boffa JJ, Tharaux PL, et al. Progression and regression in renal vascular and glomerular fibrosis. International journal of experimental pathology 2004;85:1-11.

19. Ricardo SD, van Goor H, Eddy AA. Macrophage diversity in renal injury and repair. The Journal of clinical investigation 2008; 118:3522-30.

20. Garra BS. Imaging and estimation of tissue elasticity by ultrasound. Ultrasound Q 2007;23:255-68.

21. Ophir J, Cespedes I, Ponnekanti H, et al. Elastography: a quantitative method for imaging the elasticity of biological tissues. Ultrason Imaging 1991;13:111-34.

22. Onur MR, Göya C. Ultrason Elastografi: Abdominal Uygulamalar. Turkiye Klinikleri Journal of Radiology Special Topics 2013;6:59-69.

23. Bamber J, Cosgrove D, Dietrich CF, et al. EFSUMB guidelines and recommendations on the clinical use of ultrasound elastography. Part 1: Basic principles and technology. Ultraschall Med 2013;34:169-84.

24. Ferraioli G, Tinelli C, Zicchetti M, et al. Reproducibility of realtime shear wave elastography in the evaluation of liver elasticity. Eur J Radiol 2012;81:3102-6.

25. Grenier N, Gennisson JL, Cornelis F, et al. Renal ultrasound elastography. Diagn Interv Imaging 2013;94:545-50.
26. Yu H, Wilson SR. Differentiation of benign from malignant liver masses with Acoustic Radiation Force Impulse technique. Ultrasound Q 2011;27:217-23.

27. Nightingale K, McAleavey S, Trahey G. Shear-wave generation using acoustic radiation force: in vivo and ex vivo results. Ultrasound Med Biol 2003;29:1715-23.

28. Davies G, Koenen M. Acoustic radiation force impulse elastography in distinguishing hepatic haemangiomata from metastases: preliminary observations. Br J Radiol 2011;84:939-43.

29. Frulio N, Trillaud H. Ultrasound elastography in liver. Diagn Interv Imaging 2013;94:515-34.

30. Alahdab YÖ, Yılmaz Y. Transient Elastografi (Fibroscan ${ }^{\circledR}$ ): Karaciğer Fibrozisinin Değerlendirilmesinde Yeni Ufuk. Güncel Gastroenteroloji 17:59-64.

31. Myers RP, Pomier-Layrargues G, Kirsch R, et al. Feasibility and diagnostic performance of the FibroScan XL probe for liver stiffness measurement in overweight and obese patients. Hepatology 2012;55:199-208.

32. Roulot D, Czernichow S, Le Clesiau H, et al. Liver stiffness values in apparently healthy subjects: influence of gender and metabolic syndrome. J Hepatol 2008;48:606-13.

33. Doyley MM, Bamber JC, Fuechsel F, et al. A freehand elastographic imaging approach for clinical breast imaging: system development and performance evaluation. Ultrasound Med Biol 2001;27:1347-57.

34. Havre RF, Elde E, Gilja $\mathrm{OH}$, et al. Freehand real-time elastography: impact of scanning parameters on image quality and in vitro intra- and interobserver validations. Ultrasound Med Biol 2008;34:1638-50.

35. Goya C, Hamidi C, Ece A, et al. Acoustic radiation force impulse (ARFI) elastography for detection of renal damage in children. Pediatr Radiol 2015;45:55-61.

36. Derieppe M, Delmas Y, Gennisson JL, et al. Detection of intrarenal microstructural changes with supersonic shear wave elastography in rats. Eur Radiol 2012;22:243-50.

37. Gao J, He W, Cheng LG, et al. Ultrasound strain elastography in assessment of cortical mechanical behavior in acute renal vein occlusion: in vivo animal model. Clin Imaging 2014;4:613-18.

38. Gennisson JL, Grenier N, Combe C, et al. Supersonic shear wave elastography of in vivo pig kidney: influence of blood pressure, urinary pressure and tissue anisotropy. Ultrasound Med Biol 2012;38:1559-67.

39. Holdsworth A, Bradley K, Birch S, et al. Elastography of the normal canine liver, spleen and kidneys. Vet Radiol Ultrasound 2014;55:620-7.

40. Ternifi R, Gennisson JL, Tanter M, et al. Effects of storage temperature on the mechanical properties of porcine kidney estimated using shear wave elastography. J Mech Behav Biomed Mater 2013;28:86-93.

41. White J, Gay J, Farnsworth R, et al. Ultrasound elastography of the liver, spleen, and kidneys in clinically normal cats. Vet Radiol Ultrasound 2014;55:428-34.

42. Sommerer C, Scharf M, Seitz C, et al. Assessment of renal allograft fibrosis by transient elastography. Transpl Int 2013;26:545-51. 
43. Ehman EC, Rossman PJ, Kruse SA, et al. Vibration safety limits for magnetic resonance elastography. Phys Med Biol 2008;53:925-35.

44. Bensamoun SF, Robert L, Leclerc GE, et al. Stiffness imaging of the kidney and adjacent abdominal tissues measured simultaneously using magnetic resonance elastography. Clin Imaging 2011;35:284-7.

45. Ebrahimi B, Textor SC, Lerman LO. Renal relevant radiology: renal functional magnetic resonance imaging. Clin J Am Soc Nephrol 2014;9:395-405.

46. Herzka DA, Kotys MS, Sinkus R, et al. Magnetic resonance elastography in the liver at 3 Tesla using a second harmonic approach. Magn Reson Med 2009;62:284-91.

47. Korsmo MJ, Ebrahimi B, Eirin A, et al. Magnetic resonance elastography noninvasively detects in vivo renal medullary fibrosis secondary to swine renal artery stenosis. Invest Radiol 2013;48:61-8.

48. Lee CU, Glockner JF, Glaser KJ, et al. MR elastography in renal transplant patients and correlation with renal allograft biopsy: a feasibility study. Acad Radiol 2012;19:834-41.

49. Rouviere O, Souchon R, Pagnoux G, et al. Magnetic resonance elastography of the kidneys: feasibility and reproducibility in young healthy adults. J Magn Reson Imaging 2011;34:880-6.

50. Mannelli L, Valentino M, Laffi G, et al. Functional MRI of the kidney. G Ital Nefrol 2010;27:599-608.

51. Streitberger KJ, Guo J, Tzschatzsch H, et al. High-resolution mechanical imaging of the kidney. J Biomech 2014;47:639-44.

52. Warner L, Yin M, Glaser KJ, et al. Noninvasive In vivo assessment of renal tissue elasticity during graded renal ischemia using MR elastography. Invest Radiol 2011;46:509-14.

53. Al-Dahshan M. Clinical application of transient elastography in prediction of portal hypertension related complication in patients with chronic liver diseases. J Egypt Soc Parasitol 2012;42:79-88.

54. Fahey BJ, Nelson RC, Bradway DP, et al. In vivo visualization of abdominal malignancies with acoustic radiation force elastography. Phys Med Biol 2008;53:279-93.

55. Gara N, Zhao X, Kleiner DE, et al. Discordance among transient elastography, aspartate aminotransferase to platelet ratio index, and histologic assessments of liver fibrosis in patients with chronic hepatitis C. Clin Gastroenterol Hepatol 2013;11:303-8 e1.

56. Goldschmidt I, Stieghorst H, Munteanu M, et al. The use of transient elastography and non-invasive serum markers of fibrosis in pediatric liver transplant recipients. Pediatr Transplant 2013;17:525-34.

57. Koh C, Turner T, Zhao X, et al. Liver stiffness increases acutely during sickle cell vaso-occlusive crisis. Am J Hematol 2013;88:E250-4.

58. Kummer S, Sagir A, Pandey S, et al. Liver fibrosis in recessive multicystic kidney diseases: transient elastography for early detection. Pediatr Nephrol 2011;26:725-31.

59. Liu CH, Liang CC, Huang KW, et al. Transient elastography to assess hepatic fibrosis in hemodialysis chronic hepatitis $\mathrm{C}$ patients. Clin J Am Soc Nephrol 2011;6:1057-65.
60. Mikolasevic I, Racki S, Lukenda V, et al. Nonalcoholic Fatty liver disease in renal transplant recipients proven by transient elastography. Transplant Proc 2014;46:1347-52.

61. Mikolasevic I, Racki S, Zaputovic L, et al. Nonalcoholic fatty liver disease (NAFLD) and cardiovascular risk in renal transplant recipients. Kidney Blood Press Res 2014;39:308-14.

62. Wang TY, Hall TL, Xu Z, et al. Imaging feedback of histotripsy treatments using ultrasound shear wave elastography. IEEE Trans Ultrason Ferroelectr Freq Control 2012;59:1167-81.

63. Woo S, Kim SY, Cho JY, et al. Shear wave elastography for detection of prostate cancer: a preliminary study. Korean J Radiol 2014;15:346-55.

64. Mikolasevic I, Racki S, Bubic I, et al. Chronic kidney disease and nonalcoholic Fatty liver disease proven by transient elastography. Kidney Blood Press Res 2013;37:305-10.

65. Son CY, Kim SU, Han WK, et al. Normal liver elasticity values using acoustic radiation force impulse imaging: a prospective study in healthy living liver and kidney donors. J Gastroenterol Hepatol 2012;27:130-6.

66. Arda K, Ciledag N, Aktas E, et al. Quantitative assessment of normal soft-tissue elasticity using shear-wave ultrasound elastography. AJR Am J Roentgenol 2011;197:532-6.

67. Baghani A, Eskandari H, Wang W, et al. Real-time quantitative elasticity imaging of deep tissue using free-hand conventional ultrasound. Med Image Comput Comput Assist Interv 2012;15:617-24.

68. Bharat S, Varghese T. Radiofrequency electrode vibrationinduced shear wave imaging for tissue modulus estimation: a simulation study. J Acoust Soc Am 2010;128:1582-5.

69. Song P, Urban MW, Manduca A, et al. Comb-push ultrasound shear elastography (CUSE) with various ultrasound push beams. IEEE Trans Med Imaging 2013;32:1435-47.

70. Tian F, Wang ZB, Meng DM, et al. Preliminary study on the role of virtual touch tissue quantification combined with a urinary beta2-microglobulin test on the early diagnosis of gouty kidney damage. Ultrasound Med Biol 2014;40:1394-9.

71. Goya C, Daggulli M, Hamidi C, et al. The role of quantitative measurement by acoustic radiation force impulse imaging in differentiating benign renal lesions from malignant renal tumours. Radiol Med 2015;120:296-303.

72. Goya C, Kilinc F, Hamidi C, et al. Acoustic radiation force impulse imaging for evaluation of renal parenchyma elasticity in diabetic nephropathy. AJR Am J Roentgenol 2015;204:324-9.

73. Grenier N. Imaging and renal failure: from inflammation to fibrosis. J Radiol 2011;92:323-35.

74. Tan S, Ozcan MF, Tezcan F, et al. Real-time elastography for distinguishing angiomyolipoma from renal cell carcinoma: preliminary observations. AJR Am J Roentgenol 2013;200:W369-75.

75. Dillman JR, Smith EA, Davenport MS, et al. Can ShearWave Elastography be Used to Discriminate Obstructive Hydronephrosis from Nonobstructive Hydronephrosis in Children? Radiology 2015;142884. 